\title{
LUTHERAN CLERGY IN AN ORTHODOX EMPIRE. THE APPPOINTMENT OF PASTORS IN THE RUSSO-SWEDISH BORDERLAND IN THE 18TH CENTURY
}

\author{
ANTTI RÄIHÄ* \\ University of Jyväskylä
}

\begin{abstract}
The history of the parishioners' right to participate in and influence the choice of local clergy in Sweden and Finland can be taken back as far as the late Medieval Times. The procedures for electing clergymen are described in historiography as a specifically Nordic feature and as creating the basis of local self-government. In this article the features of local self-government are studied in a context where the scope for action was being modified. The focus is on the parishioners' possibilities and willingness to influence the appointment of pastors in the Lutheran parishes of the Russo-Swedish borderlands in the 18th century. At the same time, this article will offer the first comprehensive presentation of the procedures for electing pastors in the Consistory District of Fredrikshamn. The Treaty of Åbo, concluded between Sweden and Russia in 1743, ensured that the existing Swedish law, including the canon law of 1686, together with the old Swedish privileges and statutes, as well as the freedom to practise the Lutheran religion, remained in force in the area annexed into Russia. By analysing the actual process of appointing pastors, it is possible to discuss both the development of the local political culture and the interaction between the central power and the local society in the late Early Modern era.
\end{abstract}

KEY WORDS: Lutheran Clergy, parishioners' influence, borderlands, Russia, 18th century

\section{The Consistory District of Fredrikshamn in the Russo-Swedish Borderlands}

The purpose of this article is to examine the appointment of pastors in the Lutheran parishes in the Russo-Swedish borderlands in the middle and the latter half of the 18th century. The issue discussed touches on a wider research field that concerns the relation between the central power and local societies in the early modern era and in particular the question of local self-government (Gustafsson 1989; Aronson 1992; also Blickle 1987; Harnesk 1998). The clergy has often been the object of Nordic historical research from different perspectives, and pastors have been seen in it as more or less central actors in local societies (see Markkola and Kajander 2014: 107-108ff). It seems that the parishioners' confidence in the clergymen's ability and/or willingness to provide assistance in religious and secular 
problem situations varied according to the place and time (Bergström 1991; Katajala 1994: 280-290; Linde 2000: 75-82; Räihä 2014: 607-611, especially Figure 1; see also Schmidt 1894; Tackett 1977; Crafoord 2002: $111 \mathrm{ff}$; Andresen 2008: 152161; Andresen 2012). However, in relation to mutual trust between parties research has often disregarded the question of how parishioners' opinion came into being and was fulfilled while new pastors were appointed. Despite the detailed regulations, the procedure for electing pastors in the 18th century was characterized by anything but simple.

The Consistory District of Fredrikshamn ${ }^{1}$, located in Russia's western border area between the Gulf of Finland and southern Savolax in the Government of Vyborg (also known as Old Finland), came into being in 1744 after the Treaty of Åbo concluded between Sweden and Russia in 1743. The Consistory District of Fredrikshamn was a church administrative unit that was geographically almost equivalent with the Province of Kymmenegård, i. e. the area that was annexed into Russia in 1743 (see Rajainen 1972: 122-124; Väänänen 1975: 22-25; Ranta 2000: 9-12; Knapas 2013: 164-166). The Treaty of Åbo ensured that the existing Swedish law, including the canon law of 1686, together with the old Swedish privileges and statutes, and the freedom to practise the Lutheran religion, remained in force in the Province of Kymmenegård (Granfelt 1931; Paaskoski 2012: 40-45).

\section{Map 1: Parishes in the Consistory District of Fredrikshamn, 1744-1783}

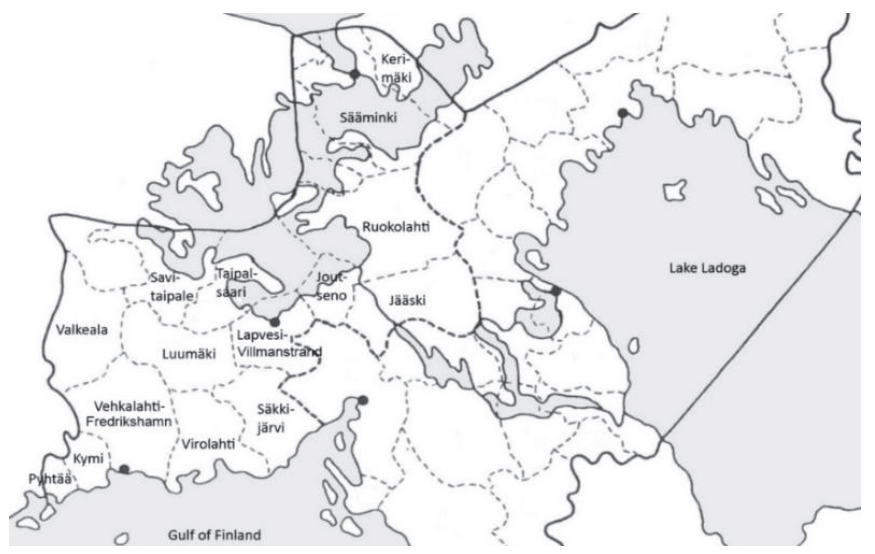

The phrase 'Diocese of Fredrikshamn' (Finnish: Haminan hïppakunta) is also employed in research literature but I prefer to use the term 'the Consistory District of Fredrikshamn'. Although there are some sporadic allusions to a 'diocese' in the sources (like dioceseos Friedrichshamnensis) there was neither a bishop at the head of the consistory nor are there references to a 'diocese' in documents concerning the establishment of the Consistory of Fredrikshamn. See e. g. Archive of the Consistory of Fredrikshamn, Received documents (8.12.1743), National Archives of Finland, Helsinki (NA); Archive of the Consistory of Fredrikshamn, Record books (22.5.1744), NA; see also Ahonen 2002: 454. 
The clergy in the Government of Vyborg have been well studied with regard to their social background, and the administrative practices of the church have likewise been explicated (Salenius 1900; Rajainen 1972; Väänänen 1975; Kansanaho 1985: 39-55; Väänänen 2000). However, the question of how clergymen were appointed to their posts both in studies of 'Old Finland' and more generally in Finnish and Nordic historical research has rarely been discussed. The interesting starting point for this study is how the procedures for electing pastors were implemented in the Lutheran parishes in the Russo-Swedish borderlands within the predominantly Orthodox Russian Empire. I will concentrate especially on the parishioners' possibilities and willingness to influence the appointment of pastors. The subject of the research will be approached through a detailed examination of the elections and the succession of pastors in all fifteen parishes within the jurisdiction of the Consistory of Fredrikshamn. The frontier agreed in 1743 split some parishes into two, and as a result the inhabitants of four parishes in the Consistory District of Fredrikshamn lived under Russian rule while most of the parishioners and also the church building stood on the other side of the border (Salenius 1877: 10-20; Favorin 1975: 233-241). The split parishes that were controlled from the Swedish side of the border are omitted from this study. The research period stretches from the birth of the consistory district in the 1740s to the early 1780s. As a consequence of Empress Catherine II's Provincial Reform and new Charters to the Towns, issued almost simultaneously in the Government of Vyborg in the mid-1780s, the procedures for appointing clergymen were also changed (Akiander 1868: 23; Sirenius 1903: 238-239; Amburger 1966: 50-53; Väänänen 1975: 26; also De Madariaga 1981: 280-281ff; LeDonne 2004: 116-122; Paaskoski 2012: 76-83; Leppik 2012).

The parishes studied in this article were subordinated to the King during the Swedish rule-in other words, the pastorates had been considered royal (Leinberg 1888: 76-77; Holmquist 1933; Matinolli 1955: 12-16). After the Treaty of Åbo they were placed under the jurisdiction of the College of Justice for Livland, Estland, and Finland Affairs in Sankt Petersburg. A resolution passed in the Swedish parliament (Riksdag) in 1731 had involved a victory for the meritocratic line that the cathedral chapters had fought for in the preceding decades. Detailed regulations for the election of clergy were issued in an ordinance issued in 1739. Any kind of informal meeting in which clerical issues were discussed were thenceforth regarded as illegal (Hannikainen 1888: 12-13, 31-32; Danielson-Kalmari 1911: 112113; Suolahti 1919: 114-115; Matinolli 1955: 32-33; Amburger 1966: 174-177; Lindström 2003: 169-175, 180-182). ${ }^{2}$ 
According to Swedish regulations, the appointment of a pastor was to be enacted in the Consistory District of Fredrikshamn after a proposal had been made by the consistory. The consistory had the right to propose three candidates among whom the parishioners should cast their votes. The votes were weighted according to the size of the homestead, although this system of counting votes was only occasionally implemented since from the 1740 s to the 1780 s tallying was most often done by a show of hands. A similar procedure was not uncommon in the parishes in the Diocese of Borgå in Swedish Finland on the other side of the border (Matinolli 1957: 54-55). Moreover, the parishioners could apply for a fourth candidate to vote for if they were not happy with the clergymen proposed by the consistory. In addition to pastors, the consistory had the right to put forward all other clergymen and pedagogues in its area (Ranta 2000: 11). ${ }^{3}$ The Consistory of Fredrikshamn was controlled from the 1740s to the 1780s by Fabian Gudseus, the cathedral dean of the Parish of Vehkalahti-Fredrikshamn. The consistory was initially made up of him and the pastors of the parishes of Lapvesi-Villmanstrand and Valkeala. In 1746 the consistory acquired a fourth member, the vice-principal (Conrector) of Fredrikshamn Trivial School (Rajainen 1972: 124-125; Ranta 2000: 9; Knapas 2013: 165). ${ }^{4}$

The empirical material for this article consists of the documents related to procedures for electing v pastors in the Consistory District of Fredrikshamn. After the elections, the consistory delivered the documents to the College of Justice for Livland, Estland and Finland Affairs. The sources further comprise electoral registers of the parishes, the Consistory of Fredrikshamn's proposals for investiture, including a description of each candidate and various correspondence and appeals, etc. related to the elections. In addition to these materials, the Consistory of Fredrikshamn's records and correspondence, and the College of Justice's short confirmations of appointments have also been exploited. Aspects such as the reasons for parishioners' absence from the polls and the advantages and disadvantages of quantitative and qualitative approaches will be highlighted in the article.

\section{Changes in Pastorates}

The election of pastors was organized quite regularly in the Consistory District of Fredrikshamn during the four decades from the birth of the consistory district to the reforms in the 1780s. In all, the office-holders of pastorates in the Consistory District of Fredrikshamn changed 33 times during the research period. ${ }^{5}$ Of these, four new pastors were appointed without an election. In the Parish of Sääminki,

3 Archive of the Consistory of Fredrikshamn, Received documents (8.12.1743), NA.

4 See Archive of the College of Justice, No. 2787, NA; Archive of the Consistory of Fredrikshamn, Received documents (25.10.1743), NA.

5 However, due to lack of source materials, the appointment processes in the parishes of Virolahti (in 1744) and Pyhtää (in 1746) are, excluding Table 1, omitted from this study; see Akiander, 1869: 199, 203, 392. 
the son of the pastor applied already in 1769 to be appointed without an election as the new pastor of the parish. The College of Justice turned down the request, but a decade later a new appeal, drawn up by the serving pastor, was approved (see Suolahti 1919: 78-80, 85-87). ${ }^{6}$ The rest of the cases of 'appointment without an election' were located geographically in the centre of the consistory district in the parishes of Taipalsaari (in 1755), Luumäki (in 1764) and LapvesiVillmanstrand (in 1779). It is rather difficult to examine these appointment processes more closely owing to the scarcity of sources, but generally it seems that the initiatives for appointing a new pastor without an election did not primarily come from the College of Justice. On the other hand, some appointments were clearly force majeure cases, as in the Parish of Luumäki, where the pastor suddenly died from an epidemic disease. ${ }^{7}$ However, the parishioners' possibility to exert some formal influence on the choice of pastor seems to have been of some importance even if an appointment had occurred without an election: in the parishes of Luumäki and Lapvesi-Villmanstrand elections were organized in the following year after new pastors were instated without an election. ${ }^{8}$

Table 1: Appointment of pastors in the Consistory District of Fredrikshamn $(n=33)$ by decennial periods, 1744-1783

\begin{tabular}{|l|l|}
\hline $1744-1753$ & 11 \\
\hline $1754-1763$ & 6 \\
\hline $1764-1773$ & 7 \\
\hline $1774-1783$ & 9 \\
\hline
\end{tabular}

Sources: Archive of the College of Justice, National Archives of Finland, Helsinki; Archive of the Consistory of Fredrikshamn, The College of Justice's orders, National Archives of Finland, Helsinki; Akiander, 1869: 199, 203, 392.

The distribution of succession in pastorates was overall quantitatively emphasized at the beginning and the end of this article's research period (Table 1). During the first decennial period (1744-1753), there were eleven changes, then six (17541763), seven (1764-1773), and finally nine new appointments from 1774 onwards. Interestingly, during the first period the changes were mainly concentrated in the years at the turn of the 1740 s and 1750s.

The procedures for electing pastors in the Consistory District of Fredrikshamn can be explored from at least three different, though in places closely interrelated, perspectives: from the points of view of the parishioners, the Consistory of Fredrikshamn and the appointing authority (the College of Justice for Livland,

$6 \quad$ Archive of the College of Justice, No. 1676, NA.

$7 \quad$ Archive of the College of Justice, No. 1378, NA.

8 Archive of the College of Justice, No. 1453, 2552, NA. 
Estland, and Finland Affairs). With regard to appointments made according to the election procedure $(n=27)$, the parishioners' favourite was instated altogether 11 times, the College of Justice's favourite seven times, and the Consistory of Fredrikshamn's four times. In addition to these, the consistory's and parishioners' shared favourites were appointed five times. All of the instated pastors were naturally the appointing authority's favourite because they received the appointment, but the category 'the College of Justice's favourite' means that the appointed pastors were neither the parishioners' favourite (i. e. they had not won the election) nor had the Consistory of Fredrikshamn placed them at the head of its proposal.

Table 2: Typology of changes $(n=31)$ in pastorates in the Consistory District of Fredrikshamn, 1744-1783

\begin{tabular}{|l|l|}
\hline Context of an appointment & Parish and year \\
\hline Appointment without an election $(\mathrm{n}=4)$ & $\begin{array}{l}\text { Taipalsaari (1755); Luumäki (1764); Lap- } \\
\text { vesi-Villmanstrand (1779); Sääminki (1779) }\end{array}$ \\
\hline Parishioners' favourite $(\mathrm{n}=11)$ & $\begin{array}{l}\text { Joutseno (1748); Lapvesi-Villmanstrand } \\
(1750) ; \text { Ruokolahti (1751); Virolahti (1751); } \\
\text { Kerimäki (1755); Pyhtää (1756); Valkeala } \\
(1759) ; \text { Luumäki (1765); Ruokolahti (1774); } \\
\text { Kymi (1778); Taipalsaari (1780) }\end{array}$ \\
\hline $\begin{array}{l}\text { Appointing authority's (i. e. the College of Justice } \\
\text { for Livland, Estland and Finland Affairs) fa- } \\
\text { vourite }(\mathrm{n}=7)\end{array}$ & $\begin{array}{l}\text { Valkeala (1751); Jääski (1762); Virolahti } \\
(1765) ; \text { Pyhtää (1771); Savitaipale (1778); } \\
\text { Lapvesi-Villmanstrand (1780); Virolahti } \\
(1782)\end{array}$ \\
\hline $\begin{array}{l}\text { The Consistory of Fredrikshamn's favourite } \\
(\mathrm{n}=4)\end{array}$ & $\begin{array}{l}\text { Säkkijärvi (1748); Luumäki (1749); Kymi } \\
(1768) ; \text { Valkeala (1773) }\end{array}$ \\
\hline $\begin{array}{l}\text { The Consistory of Fredrikshamn's and the parish- } \\
\text { ioners' shared favourite ( } \mathrm{n}=5)\end{array}$ & $\begin{array}{l}\text { Kymi (1744); Jääski (1744); Jääski (1755); } \\
\text { Kymi (1773); Joutseno (1781) }\end{array}$ \\
\hline
\end{tabular}

Sources: Archive of the College of Justice, National Archives of Finland, Helsinki; Archive of the Consistory of Fredrikshamn, The College of Justice's orders, National Archives of Finland, Helsinki.

It is difficult to find unifying geographical factors between the different types of appointments, nor does the temporal dimension seem to have any obvious connecting components. However, it appears that the College of Justice's favourite was more likely to be instated in the southern and inner parts of the consistory district while 'an appointment without an election' occurred most often in the northern parts of the area. It is also noteworthy that the parishioners' favourite was instated only once during the second decennial period (1753-1764) and the consistory's favourite not even once during the second and the fourth (1774-1783) periods (cf. Matinolli 1957: 99, 105, 113; Laasonen 1985: 73-79, 89-93). The category 'The Consistory of Fredrikshamn's and the parishioners' shared favourite' is 
interesting because the paucity of cases suggests that cooperation and consensus between the parties was not a common phenomenon (see Suolahti 1919: 110-114; Bergström 1991: 73-74; also Sandstedt 1986: 178f; Vilkuna 2005: 412-416f). To sum up, a quantitative investigation of the appointment of pastors does not bring to light any obvious chronological or geographical pattern or formula that would point to different background factors that might have influenced the nomination of pastors in the research area.

The first new pastors were appointed according to the election procedures in 1744 right after the Consistory District of Fredrikshamn was created and placed under Russian rule. ${ }^{9}$ Before that, immediately after the Treaty of Åbo, pastorates in the parishes of Sääminki, Kerimäki, Ruokolahti, and Säkkijärvi had been filled at the discretion of Lieutenant General Johan Balthasar von Campenhausen (Väänänen 1975: 92-95). ${ }^{10}$ Despite changes in the pastorates during the mid1740 s, the shift of state authority from Sweden to Russia was marked more by continuity than upheaval with regard to the stable tenure of clergymen and the regularity of the appointment of pastors per decennial periods (Tables $1 \& 2$ ). The situation was different from that which had obtained during the early decades of the 18th century during and after the Great Northern War and so called 'Great Wrath'. Although during the Great Wrath the clergy remained in their localities to a greater extent than secular officials, numerous pastors and chaplains among others nevertheless fled from the war and left their parishioners in the eastern border area of Sweden-Finland to cope under Russian occupation (Lindeqvist 1919: 449; Cederberg 1936: 27-33; Rajainen 1972: 120-122; Aminoff-Winberg 2007: 148-153; Kaukiainen 2012: 269-270).

Soon after the Treaty of Åbo, the College of Justice in St Petersburg became interested in the Swedish regulations concerning the election of clergy, and in early 1744 it ordered the Consistory of Fredrikshamn to submit to it the ordinance of 1739 on the election of clergy. ${ }^{11}$ Though the situation stayed normatively static, the old practices were modified in the Consistory District of Fredrikshamn. When the pastor of the Parish of Joutseno tendered his resignation (dimission) from his position after he was designated to the post of pastor in the Parish of Sulkava in the Swedish part of Finland, the Consistory of Fredrikshamn announced that it did not dare to grant his resignation independently (Matinolli 1957: 68). Instead, it passed on the pastor's application to the College of Justice. ${ }^{12}$

$9 \quad$ Archive of the Consistory of Fredrikshamn, The College of Justice's orders (17.8.1744; 15.11.1744), NA; Archive of the Consistory of Fredrikshamn, Record books (22.5.1744), NA.

10 Archive of the Consistory of Fredrikshamn, Received documents (18.10.1743, 27.10.1743, 31.10.1743, 4.11.1743), NA; Archive of the Consistory of Fredrikshamn, The College of Justice's orders (1.2.1745), NA; Archive of the College of Justice, No. 292, NA.

11 Archive of the College of Justice, No. 128, NA.

12 Archive of the College of Justice, No. 248, NA; Archive of the Consistory of Fredrikshamn, The College of Justice's orders (9.1.1747), NA. 


\section{The Popularity of Pastors and Consensus among Parishioners}

A quantitative typology of changes in pastorates in the Consistory District of Fredrikshamn (Table 2) indicates that in all almost 60 percent of pastors (16/27) were instated according to the election procedure after obtaining the highest number of parishioners' votes (cf. Matinolli 1957: esp. 105-106; Jutikkala 1963: 312; Sandstedt 1986; Bergström 1991: 74, 79; Linde 2000: 160-165). According to the electoral register of the Parish of Lapvesi-Villmanstrand for 1750, all townsmen in Villmanstrand, apart from one official in the Provincial Government, voted for the curate (comminister) of the parish. In Lapvesi all the voters, 185 persons in total, supported the same curate. Only eighteen parishioners who were entitled to vote were not present at the polls in rural Lapvesi. The appointment process in the Parish of Virolahti in 1751 followed a quite similar pattern, but in Ruokolahti in 1751 the electoral process was different because the parishioners' enthusiasm for voting was exactly the opposite. ${ }^{13}$ However, a mere quantitative examination of the cases does not provide answers to questions like why the parishioners' voting vigour varied significantly.

In the case of Virolahti, the Consistory of Fredrikshamn nominated three candidates out of seven contenders for the election in autumn 1750. The viceprincipal of Fredrikshamn Trivial School, for example, was omitted from the list of selected candidates both because he was unqualified and because he had campaigned for votes (rösters församlande) while he was visiting the Parish of Virolahti. ${ }^{14}$ In the Parish of Ruokolahti in 1751, in contrast to the election in Virolahti, it seems that the Consistory of Fredrikshamn failed to propose any reasonably suitable candidate for the position of pastor. The consistory even procrastinated in deciding on candidates until in October 1750 the College of Justice ordered that candidates had to be nominated so that election might take place. The College of Justice required that the pastor of the Parish of Tyris and Peterhof in Ingermanland should be one of the candidates. The clerk of the Consistory of Fredrikshamn, who was later appointed, won the election after receiving less than sixty votes since only a fifth of the over 350 parishioners who were entitled to vote were present at the polls. ${ }^{15}$ The clerk was admitted as the forth candidate in accordance with the parishioners' demand. In the opinion of the Consistory of Fredrikshamn's he was definitely not sufficiently qualified to obtain the position. ${ }^{16}$

The appointment of a pastor in the Parish of Taipalsaari in 1780 likewise turned out to be an intricate process. Initially, six candidates, including a pastor

13 Archive of the College of Justice, No. 502, 557, 566, NA.

14 Archive of the Consistory of Fredrikshamn, Record books (21.8.1750), NA; Archive of the Consistory of Fredrikshamn, Received court decisions and bulletins (16.3.1749), NA.

15 Archive of the College of Justice, No. 557, 566, NA.

16 Archive of the Consistory of Fredrikshamn, Record books (21.8.1750, 28.11.1750), NA. 
from the city of Narva in Estland, applied for the post. Later on one candidate died during the process, another contested the consistory's nomination of candidates, and finally the parishioners wanted to still have Deputy Pastor Warenberg of the Parish of Taipalsaari as a fourth candidate. The College of Justice's decreed that both Pastor Alopaeus of the city of Narva's Swedish-Finnish congregation and Deputy Pastor Warenberg should be included in the candidates along with two other contenders. Deputy Pastor Warenberg obtained the bulk of the parishioners' support, whose votes were weighted according to the size of their homesteads. However, only a few days later some parishioners in Taipalsaari called for the chaplain of the Parish of Sääminki, Anders Hæggroth, who was engaged to the departed pastor's daughter, to be instated as the parish's new pastor instead. The Consistory of Fredrikshamn rejected the suggestion as being both inappropriate and groundless. Nonetheless, the peasants announced at the end of June 1780 that they wanted to have Chaplain Hæggroth as their new pastor. According to them, 'they had the right to transfer their mandate to someone else, whom they trusted'. A couple of months later, the College of Justice appointed Anders Hæggroth as the pastor of the Parish of Taipalsaari. ${ }^{17}$

The Taipalsaari case, like the other cases where the parishioners' favourites were instated, demonstrates that dissent between the parishioners' opinion and the Consistory of Fredrikshamn's proposal for investiture was prevalent. According to Peter Lindström's study of the appointment of clergy in the Province of Hälsingland on the Swedish coast of the Gulf of Bothnia during the period 16501800 , the chapter's problems of maintaining their authority over the parishes were manifested in cases where the parishes' demands prevailed despite the chapter's preference for other candidates for the positions in question (Lindström 2003: 106-110). In the cases where the parishioners' favourite was appointed, the Consistory of Fredrikshamn had in eight of the eleven elections ranked the appointed person third or fourth, or it had not proposed the candidate in question at all. The cases in the Consistory District of Fredrikshamn also demonstrate that taking care of the previous incumbent's family was an important factor in the procedures for electing a clergy in the 18th century, as previous research has shown (Suolahti 1919: 88-94; Matinolli 1955: $117 f f ;$ Widen 1988: 33ff; Bergström 1991: $21 \mathrm{ff})$. However, it was not the only decisive factor in the parishioners' decision making because in an election in the Parish of Säkkijärvi in 1748, for example, the parishioners unanimously supported the chaplain of Säkkijärvi although the other

17 Archive of the College of Justice, No. 2532, 2632, NA; Archive of the Consistory of Fredrikshamn, The College of Justice's orders (27.4.1778, 7.8.1780), NA; Archive of the College of Justice, No. 2705, [...] at de äfwen hafwa frihet at Transportera denne fullmacht på en annan, som de hafwa förtroende till, NA; Archive of the Consistory of Fredrikshamn, Electoral registers, NA; Archive of the Consistory of Fredrikshamn, Record books (18.4.1778, 2.5.1778, 9.5.1778, 28.1.1779, 10.1.1780), NA. 
candidate, the principal of Fredrikshamn Trivial School, had promised to take care of predecessor's family and to marry the widow (see Matinolli 1957: 96-97). ${ }^{18}$

To look at the elections in which the parishioners' favourite was appointed by the College of Justice through the parishioners' voting behaviour, only in the Parish of Kymi (twice in 1744 and 1778) was the parishioners vote unanimous. However, also in elections where the parishioners' votes were split between two candidates, the difference in number of votes between the two was mainly clear. For example, in the Parish of Virolahti (in 1751) the parishioners' votes were divided: 160 against one. To conclude, the elections with unanimous votes $(n=2)$ and those in which the votes were split between two candidates $(n=9)$ shows that the parishioners' were very much of the same mind.

Table 3: Parishioners' voting behaviour in the election of pastors in which the parishioners' favourite was appointed $(n=16)$ in the Consistory District of Fredrikshamn, 17441783

\begin{tabular}{|c|c|c|c|}
\hline & Unanimous vote & $\begin{array}{l}\text { Votes split between two } \\
\text { candidates }\end{array}$ & $\begin{array}{l}\text { Votes split between } \\
\text { more than two can- } \\
\text { didates }\end{array}$ \\
\hline $\begin{array}{l}\text { Parish and } \\
\text { year }\end{array}$ & $\begin{array}{l}\text { Kymi (1744) } \\
\text { Kymi (1778) }\end{array}$ & $\begin{array}{l}\text { Jääski (1744); Joutseno } \\
\text { (1748); Lapvesi- } \\
\text { Villmanstrand (1750); } \\
\text { Virolahti (1751); } \\
\text { Pyhtää (1756); Valkeala } \\
\text { (1759); Luumäki } \\
(1765) ; \text { Taipalsaari } \\
(1780) * ; \text { Joutseno } \\
(1781)\end{array}$ & $\begin{array}{l}\text { Ruokolahti (1751); } \\
\text { Kerimäki (1755); } \\
\text { Jääski (1755); Kymi } \\
\text { (1773); Ruokolahti } \\
(1774)\end{array}$ \\
\hline
\end{tabular}

Sources: Archive of the College of Justice, National Archives of Finland, Helsinki; Archive of the Consistory of Fredrikshamn, The College of Justice's orders and Electoral registers, National Archives of Finland, Helsinki.

* The parishioners' favourite was instated, but later they changed their minds, and a new pastor was appointed at their behest.

On the other hand, elections in which the votes were split between more than two candidates $(n=5)$ indicate that the parishioners' opinion was not exclusively uniform. Even though the difference in the number of votes between the candidates was usually quite fair in these cases, too, polling in the Parish of Ruokolahti (in 1774) demonstrates that the distribution of the number of votes could sometimes be quite even. All four candidates received some votes, but two of them gained only little support, while the Parish of Sääminki's deputy pastor, Carl Henric Win- 
ter, received approximately 54 votes and the pedagogue Andreas Jokelin over sixty votes weighted according to the size of the peasants' homesteads. The result shows that the wealthier peasants supported Andreas Jokelin because, if the votes had been tallied by means of a show of hands, deputy pastor Winter would have won the election (see Suolahti 1919: 118-119). ${ }^{19}$

Table 4: Parishioners' voting behaviour in the election of pastors in which the parishioners' favourite was not appointed $(n=11)$ in the Consistory District of Fredrikshamn, 17441783.

\begin{tabular}{|c|c|c|c|}
\hline & Unanimous vote & $\begin{array}{l}\text { Votes split between } \\
\text { two candidates }\end{array}$ & $\begin{array}{l}\text { Votes split between } \\
\text { more than two candi- } \\
\text { dates }\end{array}$ \\
\hline $\begin{array}{l}\text { Parish and } \\
\text { year }\end{array}$ & Säkkijärvi (1748) & $\begin{array}{l}\text { Luumäki (1749); } \\
\text { Valkeala (1751); Jääski } \\
(1762) ; \text { Virolahti } \\
\text { (1765); Pyhtää (1771); } \\
\text { Valkeala (1773); Savi- } \\
\text { taipale (1778) }\end{array}$ & $\begin{array}{l}\text { Kymi (1768); Lapvesi- } \\
\text { Villmanstrand (1780); } \\
\text { Virolahti (1782) }\end{array}$ \\
\hline
\end{tabular}

Sources: Archive of the College of Justice, National Archives of Finland, Helsinki.

It is not easy to find any obvious difference when one compares the parishioners' voting behaviour in the election of pastors in cases where the parishioners' favourite was appointed from those in which he was passed over. Apart from the election in the Parish of Pyhtää in 1771, the difference in the ballot was quite clear when the votes were split between two candidates. Likewise, when the parishioners' support was divided between more than two candidates, the winner always received a fair majority of the votes. However, in the Parish of LapvesiVillmanstrand in 1780, the townsmen's and the peasants' opinions were opposed. The pastor of the Parish of Pyhtää received a large majority of the Lapvesi peasants' support, while the townsmen of Villmanstrand voted almost unanimously for the principal of Vyborg Cathedral School, who was the son-in law of the previous incumbent. The principal was appointed even though the number of votes received by the pastor of Pyhtää was altogether far greater. ${ }^{20}$

A closer study of the polling processes makes it possible to hypothesize that a fairly small group of parishioners were able to arrange for their own candidate to be included in the list of candidates and to ensure an electoral victory for him. This is what happened in the Parish of Ruokolahti in 1751, for example. On the

19 Archive of the College of Justice, No. 2124, NA; Archive of the Consistory of Fredrikshamn, Electoral registers, NA.

20 Archive of the College of Justice, No. 2664, NA 
other hand, the reasons for the huge non-attendance at the polling there were to a great extent practical (see Matinolli 1955: 90-93; Matinolli 1957: 55-56). According to the pastor of the Parish of Joutseno, who was the supervisor of the election in Ruokolahti, many of the peasants from Rautjärvi Chapelry in the Parish of Ruokolahti were not present because one of the contenders in the election was preaching a sermon in Rautjärvi on the day of the polls. ${ }^{21}$ Overall, the parishioners' voting behaviour in the election of pastors seems to have been to some extent influenced by the opinions of other inhabitants of the same village since the votes were only rarely split between more than two candidates even in the biggest villages in the parishes of the Consistory District of Fredrikshamn. That is to say, the opinion of the inhabitants of a single village was often unanimous while dissent between different villages was more common (see and compare Matinolli 1955: Bergström 1991: 74, 93-114; Lindström 2000: 214-223222.

Table 5: Voter turnouts in the election of pastors $\left(n=24^{*}\right)$ in the Consistory District of Fredrikshamn, 1744-1783

\begin{tabular}{|c|c|c|c|c|}
\hline & $0-25 \%$ & $26-50 \%$ & $51-75 \%$ & $76-100 \%$ \\
\hline $\begin{array}{l}\text { Parish } \\
\text { and year }\end{array}$ & $\begin{array}{l}\text { Ruokolahti } \\
(1751)\end{array}$ & $\begin{array}{l}\text { Jääski (1744); } \\
\text { Joutseno } \\
\text { (1748); Jääski } \\
\text { (1755); Jääski } \\
\text { (1762) }\end{array}$ & $\begin{array}{l}\text { Säkkijärvi (1748); } \\
\text { Kerimäki (1755); } \\
\text { Taipalsaari } \\
\text { (1780); Lapvesi- } \\
\text { Villmanstrand } \\
(1782)\end{array}$ & $\begin{array}{l}\text { Luumäki (1749); Lap- } \\
\text { vesi-Villmanstrand } \\
\text { (1750); Valkeala (1751); } \\
\text { Virolahti (1751); Pyhtää } \\
\text { (1756); Valkeala (1759); } \\
\text { Luumäki (1765); Vi- } \\
\text { rolahti (1765); Kymi } \\
\text { (1768); Kymi (1773); } \\
\text { Ruokolahti (1774); } \\
\text { Savitaipale (1778); Kymi } \\
\text { (1778); Joutseno (1781); } \\
\text { Virolahti (1782) }\end{array}$ \\
\hline
\end{tabular}

Sources: Archive of the College of Justice, National Archives of Finland, Helsinki; Archive of the Consistory of Fredrikshamn, Electoral registers, National Archives of Finland, Helsinki.

* The registers of the election of pastors in the parishes of Kymi (1744), Pyhtää (1771), and Valkeala (1773) are no longer extant.

The voter turnouts in the election of pastors in the Consistory District of Fredrikshamn from the 1740s to the 1780s (Table 5) demonstrate the parishioners' willingness to influence the course of affairs by voting. A comparison with voter turn-

21 Archive of the College of Justice, No. 566, NA.

22 See especially Archive of the Consistory of Fredrikshamn, Electoral registers (an election of a pastor in the Parish of Luumäki in 1749), NA. 
outs in the election of pastors in the Diocese of Borgå in Swedish Finland from the 1720 s to the 19th century shows an obvious difference since the parishioners' attendance at the polls in the latter parish was lower than 50 percent in almost half of the elections (Matinolli 1957: 55, 136). By contrast, voter turnout average in the consistory district during the research period was almost 75 percent, although only in the parishes of Luumäki (in 1749) and Virolahti (in 1751) did all the parishioners entitled to vote attend the polls. The parishioners' voter turnout was under 50 percent only in a fifth of the elections. As it appears, less populous parishes were no more united than larger ones, and neither the geographical size of the parishes nor the length of the distances involved seems have had much significance for voter turnouts. The lowest turnout percentages were concentrated in the central and northern parts of the area. Chronologically, the average parishioners' voter turnout in the whole district was from 1744 to 1763 about 65 percent while the average rose to over 83 percent during the period 1764-1783.

\section{Simultaneous Elections, Dissimilar Results, and Varying Practices}

An election for a new pastor was held in the Parish of Kymi in October 1778. The parishioners voted for four candidates: the principal of Fredrikshamn Trivial School, the curate of the Parish of Taipalsaari, the curate of the Parish of Joutseno and Assistant Minister (adjunct) Johan Baeckman. Baeckman was made the fourth candidate on the orders of the College of Justice. Whether the parishioners had taken the initiative in putting up Baeckman as the fourth candidate is not clear, but they, almost 150 peasants excluding a few absentees, supported him in the election. Later on, in spring 1779, Baeckman was instated as the pastor of the Parish of Kymi even though the Consistory of Fredrikshamn had not recommended him in its proposal for investiture. According to the consistory, Baeckman was not sufficiently well qualified for the position so it could not propose him as this would have been contrary to the law, privileges and instructions. The consistory had already objected to Baeckman's candidacy in February 1778 during the nomination of candidates but in vain. Unfortunately, the College of Justice's brief order authorizing Baeckman's appointment does not cast any light on the selection criteria. ${ }^{23}$

An election of a pastor in the Parish of Savitaipale was hold almost simultaneously with one in the Parish of Kymi in 1778. The deputy pastor of the Parish of Savitaipale received the majority of the parishioners' votes in the election, and he was placed in the first position in the Consistory of Fredrikshamn's proposal for investiture. The other candidates, a deputy pastor and vice-principal of Vyborg Cathedral School received some votes weighted according to the size of the voters'

23 Archive of the College of Justice, No. 2502 NA; Archive of the Consistory of Fredrikshamn, Electoral registers, NA; Archive of the Consistory of Fredrikshamn, Record books (7.2.1778), NA; Archive of the Consistory of Fredrikshamn, The College of Justice's orders (8.3.1779), NA. 
homesteads, while the deputy pastor of the city of Fredrikshamn did not get any support. Similarly, the fourth candidate, Carl Henric Winter, the deputy pastor of the Parish of Sääminki, who was nominated by order of the College of Justice, received no votes from the parishioners. The Consistory of Fredrikshamn stated that it could not include Winter among the candidates as that would have clearly been against the law. There were cogent reasons for this: for example, Winter had time after time avoided sitting his pastoral examination (... efter han altid undandragit sig Pastoral Examen). However, the College of Justice instated Winter in the position regardless of the parishioners' and the Consistory of Fredrikshamn's collected opinion. ${ }^{24}$

The election of pastors in the parishes of Kymi and Savitaipale, combined with the other above-mentioned cases indicate that it is hard to identify common factors that would explain why the parishioners' voice prevailed or failed to do so. In both the above-mentioned cases, the Consistory of Fredrikshamn's proposal for candidature was ignored though it appealed in its justification to the law and other authoritative orders. On the other hand, the parishioners' decision was realized in the Parish of Kymi. Previous research has mostly noted the percentual likelihood, mainly around 50 and 60 percent, of the parishioners getting their favourite appointed. However, more thorough analyses are generally missing from these studies. According to Peter Lindström, the rulers only half-listened to the parishioners' opinion in regal parishes in the Province of Hälsingland from the 1730s to the 1800s (Matinolli 1955: 155-157, 167-170; Sandstedt 1986: 178; Lindström 2003: 91-93).

It should also be noted that some parishes welcomed candidates who were already serving as pastors in the Consistory District of Fredrikshamn more than others. In all the elections of pastors in the parishes of Lapvesi-Villmanstrand, Ruokolahti and Virolahti from the 1740s to the 1780s at least one candidate was already serving as a pastor in the consistory district, and in the Parish of Valkeala in two thirds of the elections there were candidates who were serving pastors in the area. A pastor serving in Luumäki applied for candidacy for election in the Parish of Savitaipale in 1778, but the Consistory of Fredrikshamn rejected his application because his living was already secured..$^{25}$ Furthermore, as has been shown above, three serving pastors initially ran for the post of pastor in the Parish of Taipalsaari in 1780. On the other hand, there were no changes of incumbent in Fredrikshamn, The College of Justice's orders (23.3.1778; 30.3.1778), NA; Archive of the Consistory of Fredrikshamn, Electoral registers, NA; Archive of the Consistory of Fredrikshamn, Record books (14.9.1777) [...] så kan Consistorium twert emot tydelig Lag, ei uptaga honom ordinario loco, på något förslag til Pastorat, NA; see also the Archive of the Consistory of Fredrikshamn, Record books (12.3.1778), NA.

25 Archive of the College of Justice, No. 2491, [...] at han tidigt tilrummet sig et godt Pastorat [...] äger tilräckelig utkomst [...], NA. 
the Parish of Vehkalahti-Fredrikshamn, which was the most important pastorate of the Consistory District of Fredrikshamn because Cathedral Dean Fabian Gudseus held the office continuously from the 1740s to the 1780s (Akiander 1868: 128-129; Ranta 2000: 9; see Matinolli 1955: 75-80; Matinolli 1957: 39-53, 128129).

To look at things from another perspective, pastors serving especially in the Parish of Pyhtää seem to have been anxious to obtain a position as pastor in some other parish in the Consistory District of Fredrikshamn. The serving pastor of Pyhtää stood in two elections at the beginning of 1750 and his successor in Pyhtää in three elections at the turn of the 1770s and 1780s. Similarly, the serving pastor of the Parish of Joutseno stood in two elections: in the Parish of Virolahti in 1765 and in the Parish of Ruokolahti in 1774. However, all of these pastors had to settle for their existing positions. Only Pastor Nicander managed to change his position from the Parish of Kymi to the Parish of Valkeala in $1773 .{ }^{26}$

The election in the Parish of Valkeala in 1773 put the Consistory of Fredrikshamn in a difficult situation because it had to cut down the number of wellmatched candidates from five to three. It was difficult to reach an agreement over them whereupon each member of the consistory was required to publicly justify his opinion. According to the consistory's collective reading, despite the fact that Nicander did not possess the required extensive learning and qualifications, he had not only the most seniority of the candidates but also he had worked hard for the Fredrikshamn Trivial School and thus deserved better possibilities than the Parish of Kymi could offer (... förtjent än bättre lägenhet än Kymmene är). For these reasons the consistory, nominated Nicander for the election and put him in the first place in its ranking. However, he received only one vote, while the rest of the parishioners supported the principal of Fredrikshamn Trivial School. ${ }^{27}$ To sum up, the parishioners did not measure the candidates according to their experience and seniority because only once, in the Parish of Lapvesi-Villmanstrand in 1780, did the serving pastor of the Parish of Pyhtää receive the most votes. And this can be explained by the fact that he had previously been a chaplain in the Parish of Lapvesi-Villmanstrand. ${ }^{28}$

\section{Conclusion}

According to Martin Linde's study, it seems that pastors in the Parish of Asker in Sweden in the early 18th century were far from being spokesmen for the community even though they were elected by the peasants (Linde 2000: 165). However, to draw such direct conclusions based on materials dealing with the appointment

27 Archive of the College of Justice, No. 2063, NA; Archive of the Consistory of Fredrikshamn, Record books (28.3.1772), NA.

28 Archive of the College of Justice, No. 2664, NA. 
processes in the Consistory District of Fredrikshamn from the 1740s to the 1780s is impossible. Looking through electoral procedures the pastors' position of trust differed considerably between the parishes. Overall, the relationship between the peasants and the authorities described in this study can be regarded as a flexible interaction because the appointments were not widely questioned. The highest turnout percentages in the elections of pastors were concentrated in the southern part of the area, while in the central and northern parts voter turnouts were lower. This lower interest to influence the appointment of pastors by voting may also have some connections to the said parishioners' operations model in the late 1750s: instead of the local clergy whose assistance was emphasised in the southern parishes the peasants in the parishes in the middle of the district contacted the administrative officials in the city of Villmanstrand when they formulated complaints against a Russian mining company's misuse of power, when it operated as a landed estate across most of the Province of Kymmenegård (see Räihä 2014: 606-607).

This article has demonstrated that the parishioners wished to exert an influence over the appointment of pastors in the Consistory District of Fredrikshamn during the 18th century despite the uncertainly of the outcome. The average voter turnout actually rose towards the 1780s. Similarly, the parishioners were more or less able to make up their minds without restrictions although the opinion of their fellow villagers did influence their decisions. This leads one to assume that the practices of local communities in the procedures for electing pastors were different, although any kind of informal meetings in which the clerical issues were discussed before polling were regarded as illegal. To conclude, the parishioners' possibilities and willingness to exert an influence in the Consistory District of Fredrikshamn can be interpreted both as an active effort to preserve the old Swedish practices under Russian rule and as a passive repetition of the old operational model regardless of the outcome. The parishioners' desire to defend the old practices in the north-western borderlands of Russia seems to offer a valid explanation of the high voter turnouts in the research area as compared with those in the Diocese of Borgå on the Swedish side of the border. In connection with this, perhaps the most interesting research finding is that the parishioners were not passivized although their possibility of getting their favourite appointed according to the electoral procedure fell from over 70 percent (1744-1763) to approximately 45 percent (1764-1783). However, further studies in a comparative Nordic context are needed because as Peter Lindström mentions, the voter turnout of parishioners in the election of clergy was constantly over 90 percent in the Swedish Province of Hälsingland from the 1740s to the 1800s (Lindström 2003: 182). The regional characteristics even within one area are apparent, and the procedures for electing pastors in the Consistory District of Fredrikshamn also seem from the parishioners' perspective to differ from corresponding procedures behind the 
border in the diocese of Borgå, whereas there were many shared features with the practice of electing pastors in Hälsingland.

\section{Bibliography}

Ahonen H (2002) Artikkelikokoelma Vanhan Suomen kirkkohistoriasta. Suomen kirkkohistoriallisen seuran vuosikirja 89-91: 454.

Akiander M (1868) Herdaminne för fordna Wiborgs och nuvarande Borgå stift. I. Helsingfors: Svenska Litteratur-sällskapets tryckeri.

Akiander M (1869) Herdaminne för fordna Wiborgs och nuvarande Borgå stift. II. Helsingfors: Svenska Litteratur-sällskapets tryckeri.

Amburger E (1966) Die Geschichte der Behördenorganisation Russlands von Peter dem Grossen bis 1917. Leiden: Brill.

Aminoff-Winberg J (2007) På flykt $i$ eget land. Internflyktingar $i$ Sverige under stora nordiska kriget. Åbo: Åbo Akademi.

Andresen A (2008) Eestimaa kirikukorraldus 1710-1832. Riigivõimu mõju institutsioonidele ja õigusele. Tartu: Tartu Ülikooli Kirjastus.

Andresen A (2012) Formal stipulation and practical implementation of religious privileges in Estland, Livland and Courland under Russian supremacy. Researching the core of Baltic regional identity. Ajalooline Ajakiri 139/140: 33-54.

Aronsson P (1992) Bönder gör politik. Det lokala självstyret som social arena $i$ tre smålandssocknar, 1680-1800. Lund: Lunds universitet.

Bergström C (1991) Lantprästen. Prästens funktion i det agrara samhället 1720-1800. Oland-Frösåkers kontrakt av ärkestiftet. Stockholm: Nordiska museet.

Blickle P (1987) Communal Reformation and Peasant Piety. Central European History 20: 216-228.

Cederberg AR (1936) Vanhan Suomen ja muun Suomen välinen yhteys Uudenkaupungin rauhan jälkeen. Suomen Sukututkimusseuran vuosikirja 18: 1-68.

Crafoord F (2002) 'Läter all ting ährligha och skickeliga tilgå'. Prästerskapet i 1600-talets Sverige. Stockholm: Almqvist \& Wiksell.

Danielson-Kalmari JR (1911) Viipurin läänin palauttaminen muun Suomen yhteyteen, second edition. Helsinki: WSOY.

De Madariaga I (1981) Russia in the Age of Catherine the Great. New Haven, CT: Yale University Press.

Favorin M (1975) Mäntyharjun historia I 1860-luvulle. Mäntyharju: Mäntyharjun seurakunta.

Granfelt OH (1931) Rättskipningen i Gamla Finland under ryska tiden (17211811). Tidskrift utgiven af Juridiska Föreningen i Finland 67: 274-314.

Gustafsson H (1989) Sockenstugans politiska kultur. Lokal självstyre på 1800-talets landsbygd. Stockholm: Stadshistoriska institutet.

Hannikainen O (1888) Vanhan Suomen eli Viipurin läänin oloista 18:lla vuosisadalla. Helsinki: J. C. Frenckell ja poika. 
Harnesk B (1998) Kommunalism, makt och motmakt i det tidigmoderna Europa. Historisk Tidskrift 118(4): 635-644.

Holmquist H (1933) Tillsättningar av gäll i Sverige under reformationsårhundradet. Historisk Tidskrift 53: 90-128.

Jutikkala E (1963) Bonden i Finland genom tiderna. Helsingfors: LTs Förlag.

Kansanaho E (1985) Kirkko Karjalassa. Lappeenranta: Karjalan kirjapaino Oy.

Katajala K (1994) Nälkäkapina. Veronvuokraus ja talonpoikainen vastarinta Karjalassa 1683-1697. Helsinki: Suomalaisen Kirjallisuuden Seura.

Kaukiainen Y (2012) Kymenlaakson 1700-luku. In Kaukiainen Y (ed) Kymenlaakson historia I. Jokilaakso ja rajamaa esihistoriasta 1810-luvulle. Helsinki: Suomalaisen Kirjallisuuden Seura, pp. 262-436.

Knapas R (2013) Kirkollista ja maallista kulttuuria. In Kaukiainen Y, Marjomaa R, and Nurmiainen J (eds) Viipurin läänin historia IV. Vanhan Suomen aika. Keuruu: Otava, pp. 164-197.

Laasonen P (1985) Kyrkoherdatillsättningar i Finland under senkarolinsk tid 1690-1713. Karolinska förbundets årsbok 1985: 62-106.

LeDonne JP (2004) The Grand Strategy of the Russian Empire, 1650-1831. Oxford: Oxford University Press.

Leinberg KG (1888) Bidrag till kännedom af vårt land IV. Jyväskylä: Länkeläs förlag. Leppik L (2012) The provincial reforms of Catherine the Great and the Baltic common identity. Ajalooline Ajakiri 139/140: 55-78.

Linde M (2000): Statsmakt och bondemotstånd. Allmoge och överhet under stora nordiska kriget. Uppsala: Uppsala universitet.

Lindeqvist KO (1919) Ison vihan aika Suomessa. Porvoo: WSOY.

Lindström P (2000) Från konsensus till majoritet. Bönder, prästval och politisk kultur 1650-1800. Historisk Tidskrift 120(2): 207-225.

Lindström P (2003) Prästval och politisk kultur, 1600-1850. Umeå: Umeå universitet. Markkola P and Kajander K (2014) Paikallishistorioiden papit yhteisöissään. In Markkola P, Snellman H, and Östman A (eds) Kotiseutu ja kansakunta. Miten suomalaista historiaa on rakennettu. Helsinki: Suomalaisen Kirjallisuuden Seura, pp. 107-134.

Matinolli E (1955) Turun hiippakunnan papinvaalit ja papinvirkojen täyttäminen aikakautena 1721-1808. Turku: Turun yliopisto.

Matinolli E (1957) Porvoon hiippakunnan papinvaalit ja papinvirkojen täyttäminen aikakautena 1721-1808. Turku: Turun yliopisto.

Paaskoski J (2012) Vanhan Suomen hallintohistoria. In Orrman E and Paaskoski J (eds) Vanhan Suomen arkistot. Helsinki: Suomalaisen Kirjallisuuden Seura, pp. 17-166.

Rajainen M (1972) Luterilaisuus Venäjän valtikan alaisena. Itä-Suomen ja Inkerin kirkon järjestelyvaiheita Uudenkaupungin ja Turun rauhojen molemmin puolin. Helsinki: Suomen Kirkkohistoriallinen Seura. 
Ranta R (2000) Haminan hiippakunnan tausta, synty ja kehitys. In Keskinen K (ed) Haminan hiippakunta 1743-1812. Helsinki: Helsingin yliopisto, pp. 8-15.

Räihä A (2014) Kejsarinnas undersåte i stället för donationsbo. Bondeaktivism och rättvisenormer i 1700-talets ryska gränstrakt. Historisk Tidskrift 134(4): 587-614.

Salenius JM (1877) Niitä näitä Itä-Suomesta III. Helsinki: Hufwudstadsbla’in kirjapaino.

Salenius JM (1900) Pappien siirtymisestä Uudesta Suomesta Vanhaan Suomeen. Historiallinen Arkisto 16: 93-95.

*** (1813) Samling af Författningar och Stadgar, hwilka ändra eller förklara KyrkoLagen af År 1686, och ännu äro till efterlefnad gällande; Författad och utgifwen på Kongl. Majets Nådiga Befallning Ar 1813. Stockholm: Olof Grahn.

Sandstedt E (1986) Prästerskapets ekonomiska och sociala villkor $i$ Lunds stift 17231832. Lund: Studentlitteratur.

Schmidt O (1894) Geschichte des Kirchenpatronats in Livland. In Engelmann J, Erdmann C, von Rohland, W (eds) Dorpater Juristische Studien. Band III: 37-75.

Sirenius S (1903) Vanhan Suomen luterilaisesta kirkosta venäläisvallan aikana 1710-1812. Vartija 7/8: 225-263.

Suolahti G (1919) Suomen papisto 1600- ja 1700-luvuilla. Porvoo: WSOY.

Tackett T (1977) Priest and Parish in Eighteenth-Century France: A Social and Political Study of the Curés in a Diocese of Dauphiné 1750-1791. Princeton, NJ: Princeton University Press.

Vilkuna KHJ (2005) Viha. Perikato, katkeruus ja kertomus isostavihasta. Helsinki: Suomalaisen Kirjallisuuden Seura.

Väänänen K (1975) Pappissivistys Vanhassa Suomessa. Helsinki: Suomen Kirkkohistoriallinen Seura.

Väänänen K (2000) Haminan hiippakunnan papisto. In Keskinen, K (ed) Haminan hiippakunta 1743-1812. Helsinki: Helsingin yliopisto, pp. 16-25.

Widen S (1988) Änkeomsorg $i$ ståndssamhället. Försörjnings- och understödsformer för prästänkor $i$ Åbo stift 1723-1807. Åbo: Åbo Akademis förlag. 